\title{
STUDI KOMPARASI LIFE CYCLE COST PADA GEDUNG APARTEMEN
}

\author{
Alexander Iskandar ${ }^{1}$, Ratna S Alifen², Januar Budiman³
}

\begin{abstract}
ABSTRAK: Dalam mendesain suatu gedung apartemen yang ekonomis dan efisien, analisis life cycle cost dibutuhkan untuk mendapatkan desain yang paling efisien selama umur pakai bangunan. Berdasarkan penelitian sebelumnya, telah didapatkan bahwa biaya energi merupakan komponen biaya terbesar dalam life cycle cost suatu gedung.

Data pada penelitian ini berasal dari manajemen pengelola gedung dan beberapa supplier produk dan peralatan yang di teliti. Analisis penelitian ini dilakukan dengan menjumlahkan biaya awal $(\mathrm{C})$, biaya perawatan $(\mathrm{M})$, biaya operasional $(\mathrm{O})$, biaya penggantian $(\mathrm{R})$ dari tiap produk dan peralatan. Sebelum dijumlahkan semua biaya dikonversikan dengan metode annual cost.

Penelitian ini menunjukan bahwa penggunaan metode LCC pada saat menentukan peralatan mekanikal dan elektrikal yang digunakan pada suatu gedung apartemen dapat menghasilkan penghematan pada biaya pengelolaan gedung. Selain itu penelitian ini menunjukan bahawa sumber pendanaan awal yang berasal dari pinjaman bank tidak memberikan pengaruh terhadap pengambilan keputusan untuk pemilihan suatu produk dan peralatan yang berkaitan dengan energi.
\end{abstract}

Kata kunci: apartemen, life cycle cost, energi.

ABSTRACT: In designing an apartment building that is economical and efficient, life cycle cost analysis is needed to obtain the most efficient design for service life of the building. Based on previous studies, it has been found that the energy cost is the largest cost component in the life cycle cost of a building.

The data in this study came from the building management and from multiple suppliers of products and equipment. The analysis is done by summing the initial cost $(C)$, the cost of maintenance $(M)$, operating costs $(\mathrm{O})$, the cost of replacement $(\mathrm{R})$ of each product and equipment. Before all of the costs being added, these costs converted to annual cost method. This study shows that the use of the LCC method when determining the mechanical and electrical equipment used in an apartment building can result in savings on the building operational cost. In addition, these studies show that the source of initial funding from bank loans does not give effect to the decision making for the selection of a product and equipment related to energy.

Keyword: apartment, life cycle cost, energy.

\footnotetext{
${ }^{1}$ Mahasiswa Program Studi Magister Teknik Sipil, super_inter2000@hotmail.com

${ }^{2}$ Dosen Program Studi Magister Teknik Sipil Universitas Kristen Petra, alifrat@peter.petra.ac.id

${ }^{3}$ Dosen Program Studi Magister Teknik Sipil Universitas Kristen Petra, januar@petra.ac.id
} 


\section{PENDAHULUAN}

Dengan pertumbuhan penduduk yang besar, maka suatu kota menghadapi permasalahan keterbatasan lahan untuk pembangunan tempat tinggal. Oleh karena itu, pembangunan apartemen dijadikan pilihan karena dengan luas lahan yang sama, apartemen dapat menghasilkan jumlah hunian yang jauh lebih banyak dibandingkan perumahan.

Apartemen sering kali belum menjadi solusi bagi sebagian masyarakat oleh karena tingginya biaya pengelolaan yang dibebankan pada penghuni. Oleh karena itu, pihak pengembang perlu mempertimbangkan desain yang tidak hanya ekonomis pada saat pembangunan, melainkan juga efisien selama masa beroperasinya apartemen tersebut.

Dalam pertimbangan desain yang ekonomis dan efisien, analisis life cycle cost (LCC) dibutuhkan untuk mendapatkan desain yang paling efisien selama umur pakai bangunan, dengan memperhitungkan biaya investasi sampai bangunan beroperasi.

Penelitian-penelitian sebelumnya telah mendapatkan bahwa biaya energi merupakan komponen biaya terbesar dalam LCC suatu gedung (Tanuadji, 2010). Hal ini menjadi dasar untuk penelitian berikutnya untuk lebih memfokuskan pada desain mekanikal dan elektrikal yang berkaitan dengan energi listrik dalam melakukan studi LCC, sehingga mendapatkan gedung yang lebih efisien untuk biaya-biaya yang dikeluarkan selama umur pakai bangunan.

\section{LANDASAN TEORI}

\subsection{Apartemen}

Apartemen atau rumah susun adalah bangunan gedung bertingkat yang dibangun dalam suatu lingkungan yang terbagi dalam bagian-bagian yang distrukturkan secara fungsional, baik dalam arah horizontal maupun vertikal dan merupakan satuan-satuan yang masingmasing dapat dimiliki dan digunakan secara terpisah, terutama untuk tempat hunian yang dilengkapi dengan bagian bersama, benda bersama, dan tanah bersama (UU Nomor 20 Tahun 2011)

\subsection{Life Cycle}

Setiap produk dan sistem melewati tahapan yang sama satu dengan yang lainnya. Tahapan tersebut diawali dengan tahap pengidentifikasian kebutuhan dan diakhiri dengan tidak digunakan/diperlukan oleh penggunanya.

Life cycle dipisahkan menjadi dua periode waktu utama, yakni fase akuasisi (semua kegiatan sebelum pelaksanaan pembangunan dimulai.) dan fase operasional (operation phase). Penjabaran mengenai dua fase tersebut sebagai berikut (Blank \& Tarquin, 2005):

1. Fase akuisisi: semua kegiatan sebelum pelaksanaan pembangunan dimulai.

2. Fase operasional: semua kegiatan yang menghasilkan produk dan jasa berlangsung.

\subsubsection{Life Span}

Untuk menentukan berapa lama suatu life cycle dari tiap barang/peralatan, dapat dilihat dari (Kirk \& Dell'isola, 1995):

1. Technological life - barang/ peralatan di estimasi berdasarkan waktu yang diperlukan sampai teknologi dari barang tersebut dianggap usang.

2. Useful life - barang/ peralatan di estimasi berapa lama barang tersebut dapat memberikan performa seperti yang diharapkan dari semula.

3. Economic life - barang/ peralatan di estimasi berapa lama barang tersebut tetap memiliki nilai ekonomi dibandingkan performanya.

\subsubsection{Life Cycle Cost}

Life cycle cost memiliki definisi semua biaya yang dikeluarkan sepanjang masa pakai meliputi persiapan, desain, akuasisi dan biaya lainnya yang langsung berhubungan dengan kepemilikan atau penggunaan aset (New South Wales Treasury, 2004). 
LCC adalah salah satu alat yang digunakan pada Value Engineering untuk melakukan evaluasi terhadap beberapa alternatif yang bertujuan untuk mendapatkan nilai optimal dari total biaya yang ada, dengan penurunan biaya $5-10$ persen dari biaya yang dikeluarkan pada masa operasional bangunan (Kirk \& Dell'isola, 1995).

Untuk mengetahui perbandingan antara fase pada life cycle cost dan biaya-biaya yang ada, dapat dilihat pada Gambar 1. Dalam kondisi normal, kurang lebih $80 \%$ dari life cycle cost "terkunci" pada akhir dari tahap akuisisi yang berisikan keputusan-keputusan mengenai analisa dan detail desain bangunan. Hal tersebut kontras terlihat dari besaran biaya yang keluar selama fase akuisisi hanya sebesar $20 \%$ dibandingkan dengan total life cycle cost (DeGarmo, et all, 1997), sehingga tahap desain yang menjadi acuan paling penting untuk menghasilkan suatu life cycle cost yang efisien dan ekonomis.

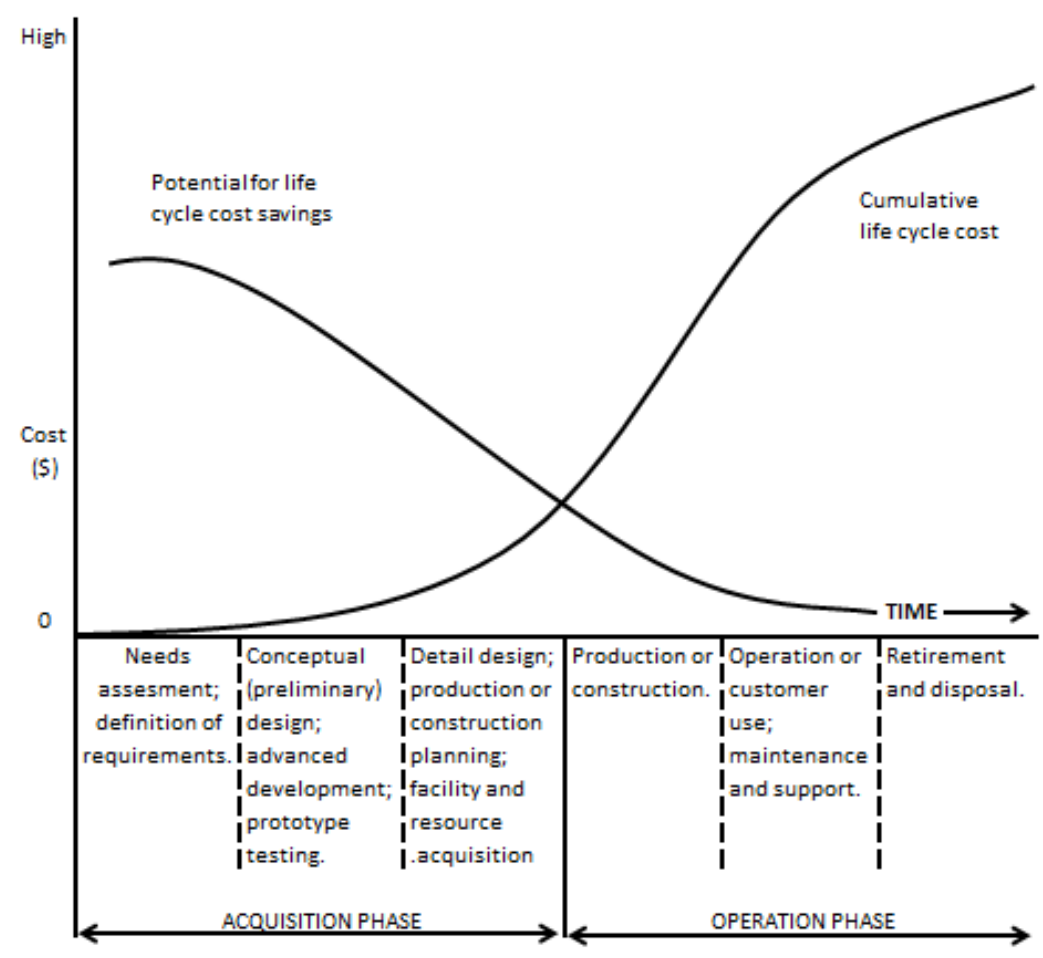

Gambar 1. Perbandingan Biaya di antara Fase Life Cycle Cost

Untuk melakukan analisis $L C C$ ada tiga hal kunci yang perlu diperhatikan, yakni (Olubodun, et all, 2010):

1. Pengumpulan data komponen biaya awal, biaya perbaikan, biaya operasional, biaya penggantian maupun biaya pembuangan.

2. Memperkirakan masa pakai dari tiap komponen biaya.

3. Memperkirakan pasar kedepan, seperti bunga bank, tingkat inflasi, maupun resiko.

\subsubsection{Inflasi}

Pada analisis LCC, hal yang menjadi fokus utama adalah pembuatan komparasi alternatif yang ada, oleh karena itu, metode constant dollar dipilih penggunaannya dibandingkan metode current dollar. Pada metode constant dollar faktor inflasi tidak dipertimbangkan (Kirk \& Dell'isola, 1995).

\subsubsection{Cara Perhitungan Life Cycle Cost}

LCC tersusun dari biaya awal, biaya perawatan dan operasional ( $\mathrm{M} \& \mathrm{O}$ Cost), biaya perubahan dan penggantian (alteration and replacement cost) serta nilai sisa (salvage value)

$\mathrm{LCC}=\mathrm{C}+\mathrm{M}+\mathrm{O}+\mathrm{R}-\mathrm{S}$ 
$\mathrm{C}=$ Biaya awal (present cost, rupiah).

$\mathrm{M}=$ Biaya perawatan (annual cost, rupiah/ tahun).

$\mathrm{O}=$ Biaya operasional (terdiri dari biaya energi dan biaya staf, annual cost, rupiah/ tahun).

$\mathrm{R}=$ Biaya penggantian dan perubahan fungsi (annual cost, rupiah/ tahun).

$\mathrm{S}=$ Salvage value (future cost, rupiah).

Karena LCC dinyatakan dalam annual cost, maka biaya awal (present worth) harus diubah menjadi annual worth dengan rumus:

$$
\begin{aligned}
A & =P \frac{i(1+i)^{N}}{(1+i)^{N}-1} \\
& =\mathrm{P}(\mathrm{A} / \mathrm{P}, \mathrm{i} \%, \mathrm{~N})
\end{aligned}
$$

Demikian pula future cost diubah menjadi annual cost dengan rumus:

$$
\begin{aligned}
A & =F \frac{1}{(1+i)^{N}-1} \\
& =\mathrm{F}(\mathrm{A} / \mathrm{F}, \mathrm{i} \%, \mathrm{~N})
\end{aligned}
$$

Untuk melakukan perhitungan annual worth, dengan beberapa future cost, maka biaya yang ada diubahkan dulu menjadi present worth dengan rumus:

$$
\begin{aligned}
P & =F \frac{1}{(1+i)^{N}} \\
& =\mathrm{F}(\mathrm{P} / \mathrm{F}, \mathrm{i} \%, \mathrm{~N})
\end{aligned}
$$

Keterangan:

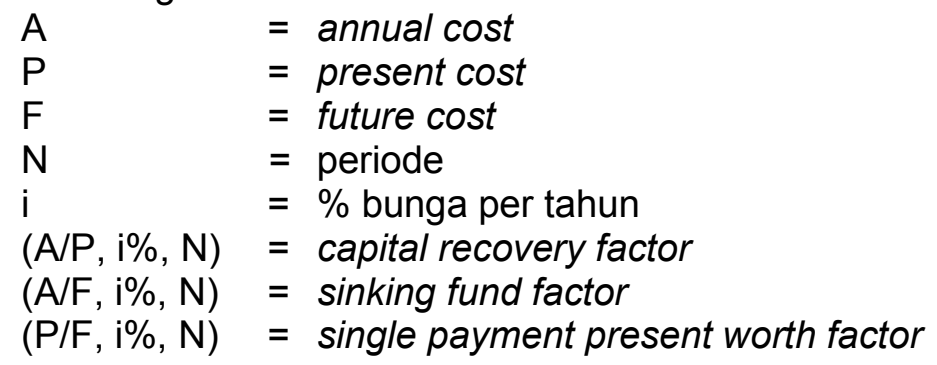

\subsection{Biaya Pengelolaan}

Dalam menjalankan pengelolaan sebuah apartemen, manajemen gedung dapat menerima sejumlah biaya pengelolaan. Besarnya biaya pengelolaan didasarkan kebutuhan nyata dari biaya operasional, pemeliharaan dan perawatan. Biaya pengelolaan dibebankan kepada pemilik dan penghuni secara proporsional (UU no 20 Tahun 2011 Pasal 57).

\subsection{Energi}

Energi secara umum adalah kemampuan untuk melakukan kerja yang dapat berupa panas, cahaya, mekanika, kimia dan elektromagnetika (UU No 30 Tahun 2007).

Definisi dari energi untuk operasional gedung adalah energi yang digunakan oleh gedung selama fase operasional, seperti untuk: pemanas, pendingin, ventilasi, air panas, pencahayaan, dan perlengkapan elektronik lainnya (Sartori \& Hestnes, 2007).

\section{METODOLOGI PENELITIAN}

Analisis data dilakukan dengan menggunakan spreadsheet software Microsoft Excel. Semua biaya awal $(\mathrm{C})$, biaya perawatan $(\mathrm{M})$, biaya operasional $(\mathrm{O})$, dan biaya penggantian $(\mathrm{R})$ dari tiap peralatan yang berkaitan dengan energi dikonversikan dengan metode annual cost, 
sehingga mendapatkan biaya yang dapat dibandingkan dari sumber yang berbeda tahun pembuatannya.

Komparasi biaya dimulai setelah semua data biaya aktual dan alternatif penggunaaan peralatan yang berkaitan dengan energi telah didapatkan, umur pakai alat, jumlah unit yang dibutuhkan, dan besar energi yang digunakan. Biaya penggunaan listrik merupakan biaya operasional dalam penggunaan peralatan tersebut.

Setiap biaya awal, biaya perawatan, biaya operasional dan biaya penggantian dari tiap alternatif peralatan dijumlahkan sehingga diperoleh nilai LCC tiap peralatan. Nilai sisa dari tiap peralatan yang telah melampaui life span dari apartemen, diasumsikan tidak dapat dijual kembali. Hasil yang ingin didapatkan adalah peralatan yang memiliki nilai LCC yang paling minimum dari tiap item pekerjaan. Hasil LCC minimum yang didapatkan dibandingkan dengan LCC eksisting, sehingga mendapatkan persentase penghematan pada tiap item pekerjaan.

\section{ANALISIS DATA DAN PEMBAHASAN}

\subsection{Life Cycle Cost Energi pada Apartemen}

Apartemen dapat dikatakan 'hidup' jika operasionalnya memenuhi kebutuhan para penghuni. Operasional dari apartemen tersebut membutuhkan energi untuk mendukungnya. Tabel 1. menunjukkan penghitungan untuk setiap item pekerjaan yang menghasilkan energi, sehingga dapat mengoperasionalkan apartemen secara optimal.

Tabel1. Hasil dari LCC Minimum

\begin{tabular}{|c|c|c|c|c|c|}
\hline \multirow{3}{*}{ Item Pekerjaan } & \multicolumn{3}{|c|}{ Alternatif } & \multirow{2}{*}{ LCC Minimum } & \multirow{2}{*}{$\begin{array}{c}\text { Persen } \\
\text { Penghematan }\end{array}$} \\
\hline & A (Eksisting) & B & $\mathrm{C}$ & & \\
\hline & (Rp) & (Rp) & (Rp) & (Rp) & $(\%)$ \\
\hline Pompa Transfer & 109.772.912 & 107.432 .727 & 106.805 .113 & 106.805 .113 & 2,70 \\
\hline Pompa Booster & 30.505 .679 & 27.399 .393 & & 27.399 .393 & 10,18 \\
\hline $\begin{array}{l}\text { Pompa } \\
\text { Submersible }\end{array}$ & 39.920 .625 & 39.025 .534 & 32.816 .243 & 32.816 .243 & 17,80 \\
\hline $\begin{array}{l}\text { Pompa kolam } \\
\text { renang }\end{array}$ & 13.754 .174 & 9.608 .615 & 9.315 .474 & 9.315 .474 & 32,27 \\
\hline $\begin{array}{l}\text { AC Area } \\
\text { Komersial dan } \\
\text { Pengelola } \\
\text { Gedung }\end{array}$ & 31.763 .566 & 30.044 .607 & 29.866 .127 & 29.866 .127 & 5,97 \\
\hline $\begin{array}{l}\text { AC Ruang Mesin } \\
\text { Lift }\end{array}$ & 33.373 .051 & 31.081 .883 & 26.605 .056 & 26.605 .056 & 20,28 \\
\hline Lift Penumpang & 685.805 .521 & 607.888 .271 & 603.638 .688 & 603.638 .688 & 11,98 \\
\hline Lift Barang & 394.848 .856 & 326.056 .939 & 352.386 .077 & 326.056 .939 & 17,42 \\
\hline Lampu Koridor & 61.457 .098 & 46.224 .432 & 63.240 .106 & 46.224 .432 & 24,79 \\
\hline $\begin{array}{l}\text { Lampu Area } \\
\text { Komersial }\end{array}$ & 2.639 .835 & 1.770 .810 & 2.568 .061 & 1.770 .810 & 32,92 \\
\hline Lampu Balkon & 21.372.376 & 21.973 .424 & 28.544 .184 & 21.372 .376 & 0,00 \\
\hline $\begin{array}{l}\text { Lampu Tangga } \\
\text { Kebakaran dan } \\
\text { Tangga } \\
\text { Penghubung } \\
\end{array}$ & 80.673 .458 & 43.548 .766 & 40.715 .582 & 40.715 .582 & 49,53 \\
\hline $\begin{array}{l}\text { Lampu } \\
\text { Penerangan } \\
\text { Jalan }\end{array}$ & 12.367 .880 & 7.956 .075 & 9.601 .324 & 7.956 .075 & 35,67 \\
\hline $\begin{array}{l}\text { Generator } \\
\text { (konsumsi } \\
\text { liter/jam) }\end{array}$ & 123.204 .154 & 127.402 .524 & 123.592 .466 & 123.204 .154 & 0,00 \\
\hline Ceiling Speaker & 6.188 .155 & 8.327.046 & & 6.188 .155 & 0,00 \\
\hline Total & 1.647 .647 .340 & & & 1.409 .934 .618 & 14,43 \\
\hline
\end{tabular}


Dari Tabel 1. dapat dilihat bahwa jika semua LCC energi minimum dari tiap item pekerjaan digabungkan menjadi satu, dihasilkan persentase penghematan sebesar $14,43 \%$, sedangkan Gambar 2. memperlihatkan besar pengaruh dari tiap produk dan peralatan terhadap total LCC energi.

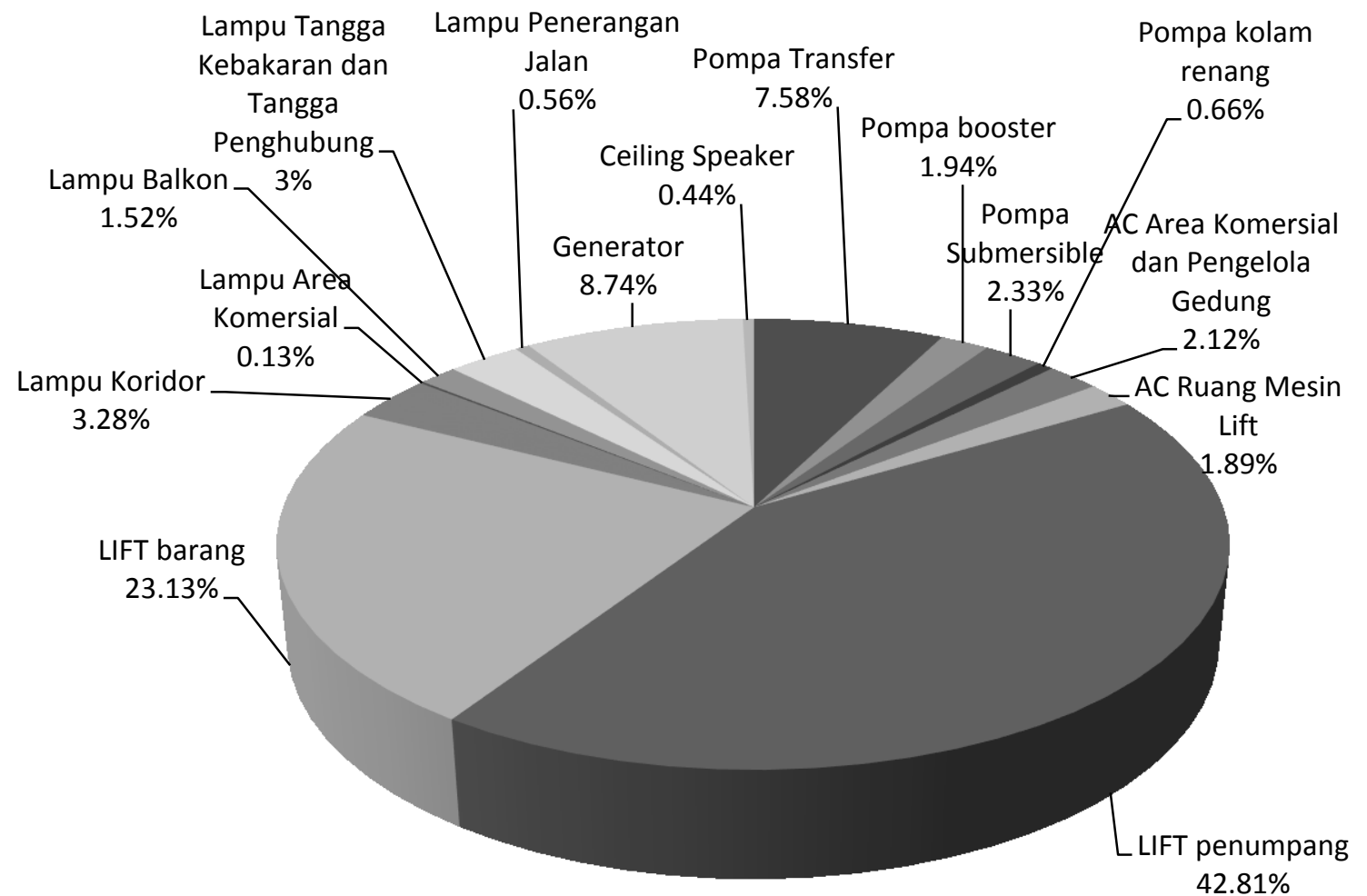

Gambar 2. Persentase Pengaruh dari Tiap Item Pekerjaan terhadap Life Cycle Cost Energi pada Apartemen

Dari Gambar 2. dapat terlihat bahwa penggunaan lift sangat berperan sentral terhadap total LCC dari sebuah gedung apartemen. Persentase LCC pada gabungan antara lift penumpang maupun barang melebihi $60 \%$ dari keseluruhan biaya energi yang dikeluarkan oleh gedung sampai berakhirnya life span dari gedung tersebut. Sehingga pemilihan penggunaan suatu produk lift sangat penting untuk diteliti secara cermat.

\subsection{Efisiensi Biaya Pengelolaan Gedung}

Biaya pengelolaan dari tiap gedung apartemen dapat berbeda-beda sesuai kebijakan dari masing-masing pengelola gedung. Besaran biaya pengelolaan didasarkan atas kebutuhan nyata dari biaya operasional, pemeliharaan dan penggantian. Dengan penggunaan metode LCC untuk menentukan besaran biaya pengelolaan, diharapkan biaya yang dibebankan kepada penghuni apartemen tersebut paling minimum.

Untuk mengetahui pengaruh dari metode LCC terhadap penurunan biaya pengelolaan gedung, dapat dilihat pada Tabel 2. Biaya pengelolaan eksisting yang didapatkan dari pengelola gedung adalah $\mathrm{Rp} 244.000 .000 /$ bulan. Biaya tersebut dibagi per $\mathrm{m}^{2}$ luas total unit yang dimiliki oleh penghuni. Rp 244.000.000/bulan : 24.077,25 $\mathrm{m}^{2}=\mathrm{Rp} 10.134 / \mathrm{bulan} / \mathrm{m}^{2}$, sedangkan biaya pengelolaan hasil studi LCC adalah (Rp 244.000.000 - Rp 24.907.971) : $24.077,25 \mathrm{~m}^{2}=\mathrm{Rp} 9.100 / \mathrm{bulan} / \mathrm{m}^{2}$, sehingga besar persentase penurunan biaya pengelolaan gedung didapatkan sebesar $10,20 \%$. 
Tabel. 2. Perbandingan Biaya Operasional, Biaya Penggantian, dan Biaya Perawatan Apartemen Berdasarkan LCC

\begin{tabular}{|c|c|c|c|c|}
\hline \multirow{3}{*}{$\begin{array}{l}\text { Jenis } \\
\text { Item } \\
\text { Pekerjaan }\end{array}$} & \multirow{3}{*}{$\begin{array}{l}\text { Jenis } \\
\text { Sistem }\end{array}$} & \multirow{3}{*}{ Jenis Peralatan } & \multicolumn{2}{|c|}{ Biaya Operasional } \\
\hline & & & LCC Existing & LCC Minimum \\
\hline & & & (Rp) & (Rp) \\
\hline \multirow{8}{*}{ Mekanikal } & \multirow{4}{*}{ Pemipaan } & Pompa Transfer & 105.099 .648 & 104.534 .121 \\
\hline & & Pompa booster & 25.887 .200 & 25.295 .285 \\
\hline & & Pompa Submersible & 38.322 .694 & 31.831 .679 \\
\hline & & Pompa kolam renang & 11.503 .175 & 8.088 .740 \\
\hline & \multirow{2}{*}{$\begin{array}{l}\text { Tata Udara } \\
\text { dan } \\
\text { Ventilasi }\end{array}$} & $\begin{array}{l}\text { AC Area Komersial dan } \\
\text { Pengelola Gedung }\end{array}$ & 29.000 .753 & 27.782 .980 \\
\hline & & AC Ruang Mesin Lift & 31.982 .196 & 25.628 .670 \\
\hline & \multirow{2}{*}{$\begin{array}{l}\text { Transportasi } \\
\text { dalam } \\
\text { Gedung }\end{array}$} & LIFT penumpang & 590.842 .746 & 468.499 .354 \\
\hline & & LIFT barang & 341.432 .295 & 253.008 .651 \\
\hline \multirow{5}{*}{ Elektrikal } & \multirow{5}{*}{ Penerangan } & Lampu Koridor & 59.675 .355 & 40.655 .294 \\
\hline & & Lampu Area Komersial & 2.544 .809 & 1.473 .789 \\
\hline & & Lampu Balkon & 20.312 .739 & 20.312 .739 \\
\hline & & $\begin{array}{l}\text { Lampu Tangga Kebakaran } \\
\text { dan Tangga Penghubung }\end{array}$ & 80.095 .424 & 36.490 .215 \\
\hline & & Lampu Penerangan Jalan & 11.451 .600 & 5.653 .466 \\
\hline Elektrikal & $\begin{array}{l}\text { Distribusi } \\
\text { Daya Listrik }\end{array}$ & Genset (konsumsi liter/jam) & 93.005 .991 & 93.005 .991 \\
\hline Elektronik & Tata Suara & Ceiling Speaker & 2.505 .966 & 2.505 .966 \\
\hline \multicolumn{3}{|c|}{ Penghematan (Eksisting-Minimum) } & & 298.895 .650 \\
\hline \multicolumn{3}{|c|}{ Penghematan per Bulan } & & 24.907 .971 \\
\hline \multicolumn{3}{|c|}{ Biaya Pengelolaan Eksisting } & & 244.000 .000 \\
\hline \multicolumn{3}{|c|}{ Biaya Pengelolaan LCC Minimum } & & 219.092 .029 \\
\hline
\end{tabular}

\section{KESIMPULAN}

1 Pemilihan peralatan mekanikal dan elektrikal dengan cara komparasi LCC energi dapat menghasilkan penghematan sebesar $14,43 \%$.

2 Pada item pekerjaan mekanikal, persentase penghematan terbesar terdapat pada penggantian pompa kolam renang, yakni sebesar $32,27 \%$.

3 Pada item pekerjaan elektrikal, persentase penghematan terbesar terdapat pada penggantian tipe lampu pada tangga kebakaran dan tangga penghubung, yakni sebesar $49,53 \%$.

4 Pada item pekerjaan elektronik tidak terdapat penghematan dikarenakan peralatan yang digunakan telah memiliki nilai LCC yang paling minimum.

5 Pemilihan merek lift penumpang dan lift barang harus dipilih secara teliti dengan metode LCC disebabkan memiliki persentase pembiayaan lebih dari $60 \%$ terhadap keseluruhan biaya LCC energi.

6 Pada jenis peralatan pompa transfer, pompa kolam renang, AC, lift, lampu balkon, lampu tangga kebakaran, lampu penerangan jalan dan generator, pembiayaan operasional sangat mendominasi perhitungan LCC peralatan tersebut dengan persentase pembiayaan lebih dari $60 \%$ dari total LCC energi apartemen. 
7 Biaya perawatan sangat mendominasi pembiayaan penggunaan pompa booster dengan persentase pembiayaan lebih dari $60 \%$ dari total LCC energi apartemen.

8 Dengan menggunakan metode LCC dapat menghasilkan penurunan biaya pengelolaan gedung sebesar $10,20 \%$.

\section{DAFTAR REFERENSI}

Blank, Leland P.E., \& Tarquin, Anthony P.E. (2005). Engineering Economy (6th ed.). McGrawHill, 1221 Avenue of the Americas, New York.

DeGarmo, E.Paul., Sullivan, William G., Bontadelli, James A., \& Wicks, Elin M. (1997). Engineering Economy (10th ed.). Prantice Hall, Upper Sadle River, New Jersey.

Indonesia., Undang-Undang Republik Indonesia Nomor 20 Tahun 2011 tentang Rumah Susun.

Indonesia., Undang-Undang Republik Indonesia Nomor 30 Tahun 2007 tentang Energi.

Kirk, Stephen., \& Dell'isola, Alphonse. (1995). Life Cycle Costing for Design Profesionals. McGraw-Hill, Inc. New York.

New South Wales Treasury. (2004). Life Cycle Costing Guideline.NSW Treasury, New South Wales

Olubodun, Femi., Kangwa, Joseph., Oladapo, Adebayo., \& Thompson, Judith. (2010). An Appraisal of the Level of Application of Life Cycle Costing within the Construction Industry in the UK. Journal Structural Survey, Vol. 28 No.4, pp. 254-265.

Sartori, I., \& Hestnes, A.G. (2007). Energy Use in the Life Cycle of Conventional and LowEnergy Buildings. Journal Energy and Buildings, Vol. 39, 2007, pp.249-257.

Tanuadji, Irwan.T. (2010). Model Simulasi Life Cycle Cost untuk Fasilitas Bangunan Perguruan Tinggi, Unpublised undergraduate thesis, Universitas Kristen Petra, Surabaya. 